\title{
Are Early Summer Wildfires an Opportunity to Revegetate Exotic Annual Grass-Invaded Plant Communities?
}

\author{
Kirk W. Davies, ${ }^{1}$ Aleta M. Nafus, ${ }^{2}$ and Dustin D. Johnson ${ }^{3}$ \\ Authors are ${ }^{1}$ Rangeland Scientist and ${ }^{2}$ Research Assistant, USDA-ARS Eastern Oregon Agricultural Research Center, Burns, OR 97720, USA; and \\ ${ }^{3}$ Assistant Professor, Oregon State University, Burns, OR 97720, USA.
}

\begin{abstract}
Medusahead (Taeniatherum caput-medusae [L.] Nevski) is an exotic annual grass invading western rangelands. Successful revegetation of invaded-plant communities can be prohibitively expensive because it often requires iterative applications of integrated control and revegetation treatments. Prescribed burning has been used to control medusahead and prepare seedbeds for revegetation, but burning has been constrained by liability concerns and has produced widely varying results. Capitalizing on naturally occurring wildfires could reduce revegetation costs and alleviate liability concerns. Thus, our objective was to determine if early summer wildfires and fall drill seeding could be used as a treatment combination to decrease medusahead and increase perennial and native vegetation. Treatments were evaluated pretreatment and for $3 \mathrm{yr}$ postfire at six sites and included 1) an early summer wildfire combined with a seeding treatment (burn and seed) and 2) a nontreated (no burn, no seed) control. Perennial grass density was 4.6- to 10.0-fold greater in the burn-and-seed treatment compared to the control in the first $3 \mathrm{yr}$ posttreatment $(P<0.05)$. Exotic annual grass density and cover in the third year posttreatment were lower in the burn-and-seed treatment than in the control $(P<0.05)$. However, exotic annual grass density was still $>130$ individuals $\cdot \mathrm{m}^{-2}$ in the burn-andseed treatment. The density of exotic annual grass is of concern because over time medusahead may displace perennial grasses and annual forbs that increased with the burn-and-seed treatment. Though not directly tested in this study, we suggest that, based on other research, the burn-and-seed treatment may need to incorporate a preemergent herbicide application to further suppress medusahead and increase the establishment of seeded vegetation. However, it appears that early summer wildfires may provide an opportunity to reduce the cost of integrated programs to revegetate medusahead-invaded plant communities.
\end{abstract}

Key Words: invasive plants, medusahead, restoration, sagebrush, Taeniatherum caput-medusae, weeds

\section{INTRODUCTION}

Invasive annual grasses are a serious threat to rangelands around the world (Purdie and Slatyer 1976; Mack 1981; Brooks et al. 2004; Liu et al. 2006). One of the most problematic exotic annual grasses in western North America is medusahead (Taeniatherum caput-medusae [L.] Nevski; Young 1992). Invasion by medusahead is a major force of change and threatens ecosystem processes and function (Davies 2011). It reduces biodiversity, degrades habitat value, decreases livestock forage production, and increases fine fuel loads (Davies and Svejcar 2008; Davies 2011). Hironaka (1961) estimated that medusahead invasion decreases livestock production by $80 \%$. Litter accumulations from medusahead suppress native plants and can increase wildfire frequency (Torell et al. 1961; Davies and Svejcar 2008). Increases in fire frequency associated with exotic annual grass invasion can be especially detrimental to native vegetation, promote the continued dominance of the plant community by exotic annual grasses, and facilitate the invasion of adjacent areas (D'Antonio

Mention of a proprietary product does not constitute a guarantee or warranty of the product by USDA or the authors and does not imply its approval to the exclusion of other products that also may be suitable. USDA is an equal opportunity provider and employer.

Correspondence: Kirk Davies, USDA-ARS Eastern Oregon Agricultural Research Center, 67826-A Hwy 205, Burns, OR 97720, USA. Email: kirk.davies@oregonstate.edu

Manuscript received 5 March 2012; manuscript accepted 5 August 2012

(c) 2013 The Society for Range Management and Vitousek 1992; Brooks et al. 2004). Medusahead can also displace and exclude native vegetation through competition for resources (Hironaka and Sindelar 1975; Young and Mangold 2008).

Revegetation of medusahead-invaded plant communities is often unsuccessful (Young 1992; Monaco et al. 2005) or requires a combination of control treatments (Davies 2010; Davies and Sheley 2011). Combinations of burning and preemergent herbicide application followed by seeding perennial grasses have been used to successfully revegetate medusahead-invaded plant communities, but this strategy requires multiple entries and is therefore expensive (Davies 2010). Medusahead has invaded millions of hectares of western rangeland (Duncan et al. 2004), suggesting a critical need for cost-effective revegetation strategies. Less expensive, singleentry control treatments have been suggested, such as prescribed burning (Young et al. 1972; Kyser et al. 2008). In sagebrush (Artemisia L.) plant communities, prescribed burning is generally limited to late summer to fall and, sometimes, spring applications, and these burns have generally not been successful at controlling medusahead without an application of a preemergent herbicide (Young et al. 1972; Kyser et al. 2008; Davies 2010; Davies and Sheley 2011). However, prescribed burning is more effective if applied during the summer when medusahead growth is nearing completion and prior to seed maturity than later in the year (Murphy and Lusk 1961; McKell et al. 1962; DiTomaso et al. 2006). Prescribed burning in the summer is limited in most sagebrush plant communities in the Intermountain West by unacceptably high wildfire risk 
and associated liability. However, naturally occurring wildfires during the summer may offer an opportunity to prepare medusahead-invaded plant communities for revegetation efforts without having to expend resources to control medusahead and create a favorable seedbed.

Wildfires in early to mid-July of 2007 burned six of 19 medusahead-invaded plant communities where vegetation cover and density had been measured in late May to early June for a different study (Davies and Svejcar 2008). The wildfires occurred near the end of the growing season for medusahead and prior to seed maturity. These burned, medusahead-invaded plant communities were seeded with a mixture of native and introduced species that fall, providing an opportunity to evaluate the potential for opportunistically combining seeding treatments with early summer wildfires for revegetating medusahead-invaded plant communities.

The objective of this study was to determine the potential for early summer wildfires followed by seeding (burn-and-seed treatment) to reduce medusahead dominance and increase perennial and native vegetation. Our hypotheses were that 1) medusahead cover and density would be less in the burn-andseed treatment compared to the nontreated (no burn, no seed) control, 2) cover and density of other plant functional groups, excluding exotic annual grasses, would be greater in the burnand-seed treatment than in the control, and 3) bare ground would be greater in the burn-and-seed treatment compared to the control. We expect more bare ground in the burn-and-seed treatment because of a reduction in the medusahead thatch layer.

\section{METHODS}

\section{Study Area}

This study was conducted in medusahead-invaded sagebrush steppe plant communities approximately $65 \mathrm{~km}$ to $85 \mathrm{~km}$ east of Burns, Oregon (lat $43^{\circ} 28^{\prime} 48^{\prime \prime} \mathrm{N}$, long $119^{\circ} 43^{\prime} 12^{\prime \prime} \mathrm{W}$ ). Maximum distance between study sites was $22 \mathrm{~km}$. Elevation at the study sites ranged from $1100 \mathrm{~m}$ to $1300 \mathrm{~m}$. Slopes were $2-7^{\circ}$ and aspect was variable. Soils were a complex series with surface textures ranging from clayey to loamy clay and moderate to high shrink-swell potential (USDA-Natural Resource Conservation Service 2008). Soils were moderately deep with varying levels of rockiness. Long-term annual precipitation averaged approximately $350 \mathrm{~mm}$ with the majority falling as rain or snow during the October to March period (Oregon Climate Service 2009). Crop-year (1 October30 September) precipitation was $80 \%, 66 \%, 87 \%$, and $101 \%$ of the long-term average in 2007, 2008, 2009, and 2010, respectively (Eastern Oregon Agricultural Research Center, unpublished data, 2011). Moderate utilization by domestic livestock (40-50\% forage use) occurred across the study area prior to initiation of the study; however, livestock were excluded during the study. Prior to treatment all study sites (treated plots and untreated controls) were near-monocultures of medusahead. All study sites had lost the shrub overstory in wildfires prior to this study. Native perennial grass seed bank was probably depleted because of the medusahead dominance of the plant community, but was not measured. Potential natural plant communities (noninvaded) would have had an overstory dominated by Wyoming big sagebrush (Artemisia tridentata subsp. wyomingensis [Beetle \& A. Young] S.L. Welsh) or low sagebrush (Artemisia arbuscula Nutt.) and a herbaceous understory dominated by bluebunch wheatgrass (Pseudoroegneria spicata [Pursh] A. Löve) or bluebunch wheatgrass-Thurber's needlegrass (Achnatherum thurberianum [Piper] Barkworth) depending on site. Common forbs would have included hawksbeard (Crepis sp. L.), desert parsley (Lomatium sp. Raf.), milkvetch (Astragalus sp. L.), long-leafed phlox (Phlox longifolia Nutt.), tailcup lupine (Lupinus caudatus Kellogg), and little blue-eyed Mary (Collinsia parviflora Lindl.).

\section{Experimental Design and Measurements}

A complete block design was used to evaluate vegetation responses to treatments at six sites. Wildfires in July of 2007 burned six medusahead-invaded plant communities that had been sampled earlier in the year for another study. Weather conditions during the wildfires were extreme with air temperatures of up to $39^{\circ} \mathrm{C}$, relative humidity as low as $7 \%$, and wind gusts to $54 \mathrm{~km} \cdot \mathrm{h}^{-1}$. Each of the six burned medusahead-invaded plant communities was blocked with an unburned medusahead-invaded plant community that had similar topography, soils, and vegetation characteristics. Each of the unburned communities was also sampled prior to the wildfire events. The burned plant communities were seeded with a rangeland drill (Laird Welding and MFG Works, Merced, CA) in October of 2007. The seed mix included $4.50 \mathrm{~kg} \cdot \mathrm{ha}^{-1}$ (pure live seed) of crested wheatgrass (Agropyron cristatum L.), $2.20 \mathrm{~kg} \cdot \mathrm{ha}^{-1}$ of Siberian wheatgrass (Agropyron sibiricum [Wild.] Beauv.), $2.25 \mathrm{~kg} \cdot \mathrm{ha}^{-1}$ of bluebunch wheatgrass, $1.12 \mathrm{~kg} \cdot \mathrm{ha}^{-1}$ of Snake River wheatgrass (Elymus wawawaiensis J. Carlson \& Barkworth), $0.56 \mathrm{~kg} \cdot \mathrm{ha}^{-1}$ of basin wildrye (Leymus cinereus [Scribn. \& Merr.] A. Löve), $0.56 \mathrm{~kg} \cdot \mathrm{ha}^{-1}$ of squirreltail (Elymus elymoides [Raf.] Swezey), $0.56 \mathrm{~kg} \cdot \mathrm{ha}^{-1}$ of Sandberg bluegrass (Poa secunda J. Presl), and $0.14 \mathrm{~kg} \cdot \mathrm{ha}^{-1}$ Lewis flax (Linum lewisii Pursh). The seed mix contained the same species in the same proportions and was applied at the same rate as the seed mix the Bureau of Land Management seeded after large wildfires in this region in 2007. All seeds were from commercially available seed sources. The treatments were 1) the burned and seeded plant communities (burn-and-seed treatment) and 2) the plant communities that were not burned and not seeded (control treatment). A burn treatment without seeding was not included in this study because previous research has shown that burning without seeding does not increase perennial grasses in medusahead infestations in this ecosystem (Davies and Sheley 2011).

Vegetation characteristics were measured prior to treatment (2007) and for three years posttreatment (2008, 2009, and 2010). Sampling of vegetation occurred from late May to midJune in each year. One representative, but randomly located $50 \times 80 \mathrm{~m}$ plot $(0.4 \mathrm{ha})$ was used to sample each treatment in each block. Four 50-m transects were placed perpendicular to the $80-\mathrm{m}$ transect at $20-\mathrm{m}$ intervals. Herbaceous canopy cover and density were measured by species inside $40 \times 50 \mathrm{~cm}$ frames $\left(0.2 \mathrm{~m}^{2}\right)$ located at $3-\mathrm{m}$ intervals on each transect line (starting at $3 \mathrm{~m}$ and ending at $45 \mathrm{~m}$ ), resulting in 15 frames per transect and 60 frames per plot. Canopy cover was visually estimated 
inside the $0.2-\mathrm{m}^{2}$ frames. Functional group and total vegetation cover values were determined by adding individual species measurements together. Bare ground was also visually estimated in the $40 \times 50 \mathrm{~cm}$ frames.

\section{Statistical Analysis}

To determine the effects of treatments on vegetation characteristics, repeated measures analyses of variance with years as the repeated factor were used to analyze the data using the PROC MIX method in SAS version 9.1 (SAS Institute Inc., Cary, NC). Fixed variables were treatment and year and their interaction. Random variables were block and block by treatment interactions. The appropriate covariance structures were selected using the Akaike's Information Criterion (Littell et al. 1996). Treatment replicates were the 0.4-ha treatment plots in each block. Because most response variables varied by the interaction between treatment and year and we were interested in treatment effects in individual years, treatment effects were also evaluated in each year of the study. Differences between means were considered significant at alpha $\leq 0.05$. Data that violated assumptions of normality were log-transformed prior to analyses, but are presented in the graphs in their original dimensions (i.e., nontransformed). For analyses, herbaceous cover and density were grouped into functional groups: native perennial grass (excluding Sandberg bluegrass), introduced perennial grass, Sandberg bluegrass, perennial forbs, annual forbs, and exotic annual grasses (largely comprising medusahead). Sandberg bluegrass was treated as a separate functional group from the other native perennial grasses because of its relatively small stature and early development compared to other perennial grasses in these plant communities (Davies 2008; James et al. 2008). Sandberg bluegrass also responds to disturbances differently than other perennial grasses in these ecosystems (McLean and Tisdale 1972; Winward 1980; Yensen et al. 1992). Introduced and native perennial grasses were treated as separate functional groups because introduced perennial grasses are often more successful than natives in revegetation projects (Robertson et al. 1966; Hull 1974; Boyd and Davies 2010). We also analyzed introduced and native perennial grass responses as individual functional groups because increasing pressure is being placed on land managers to seed natives and these seeds are much more expensive than introduced perennial grass seeds. Introduced and native perennial grass (excluding Sandberg bluegrass) values were combined to determine total perennial grass (hereafter referred to as perennial grass) cover and density. The annual forb functional group largely consisted of native annual forbs.

\section{RESULTS}

\section{Density}

Sandberg bluegrass, perennial grass (other than Sandberg bluegrass), native perennial grass, and introduced perennial grass density varied by the interaction between year and treatment (Fig. $1 ; P<0.01$ ). Sandberg bluegrass density did not differ between treatments prior to treatment or in the first $2 \mathrm{yr}$ posttreatment (Fig. 1A; $P>0.05$ ). In the third year posttreatment, Sandberg bluegrass density was 1.8-fold greater in the untreated control compared to burn-and-seed treatment. Perennial grass density (native and introduced species) did not vary by treatment prior to treatment (Fig. 1B; $P=0.11$ ). In the three posttreatment years, perennial grass density was 4.6 - to 10.0 -fold higher in the burn-and-seed treatment compared to the control treatment $(P<0.01)$. Native perennial grass density was not different between treatments prior to burning (Fig. $1 \mathrm{C} ; P=0.11$ ). After treatments were applied, native perennial grass densities were 3.3- to 6.2-fold greater in the burn-and-seed treatment compared to the control treatment $(P<0.05)$. Introduced perennial grasses were not found in either treatment in 2007 (Fig. 1D). The burn-and-seed treatment had greater introduced perennial grass density than the control in all posttreatment years $(P<0.01)$. Exotic annual grass and annual forb density did not vary by the interaction between treatment and year $(P>0.05)$. When pooled across years, exotic annual grass density was greater in the untreated control compared to the burn-and-seed treatment $(P<0.01)$. Annual grass density was similar in the control and the burnand-seed treatments prior to treatment (Fig. $1 \mathrm{E} ; P=0.53$ ). In 2008 and 2010, annual grass density was 3.4- and 2.6-fold greater in the control than the burn-and-seed treatment, respectively $(P<0.01)$. In 2009 , annual grass density did not differ between treatments $(P=0.26)$. When all years were analyzed together, no difference in annual forb density was detected between treatments $(P=0.48)$. Annual forb density only varied between treatments in the third year posttreatment (Fig. 1F). In 2010, annual forb density was 1.6-fold greater in the burn-and-seed than the control treatment $(P<0.01)$. Perennial forb density did not vary by treatment or by the interaction between treatment and year (data not presented; $P>0.05$ ).

\section{Cover}

Sandberg bluegrass, perennial grass, and introduced perennial grass cover varied by the interaction between year and treatment (Fig. 2; $P<0.05$ ), while native perennial grass did not $(P=0.36)$. Sandberg bluegrass cover did not differ between treatments prior to treatment and in the first $2 \mathrm{yr}$ posttreatment (Fig. 2A; P>0.05). In 2010, Sandberg bluegrass cover was greater in the control than the burn-and-seed treatment $(P=0.04)$. Perennial grass cover did not differ between treatments in 2007 (Fig. 2B; $P=0.10$ ), but was between 4.8and 12.8 -fold greater in the burn-and-seed treatment compared to the control treatment in the $3 \mathrm{yr}$ after treatment $(P<0.05)$. Introduced perennial grass cover did not vary by treatment prior to treatment or in the first year posttreatment (Fig. 2D; $P>0.05)$. In 2009 and 2010, introduced perennial grass cover was greater in the burn-and-seed treatment compared to the control treatment $(P<0.01)$. When all posttreatment years were analyzed together, native perennial grass cover was greater in the burn-and-seed compared to the control treatment $(P=0.02)$. Prior to treatment, native perennial grass cover did not vary by treatment (Fig. $2 \mathrm{C} ; P=0.10$ ). Native perennial grass cover was 3.8- to 10.7 -fold greater in the burn-and-seed treatment than the control treatment in the $3 \mathrm{yr}$ after treatment $(P<0.05)$. Exotic annual grass cover did not differ between 


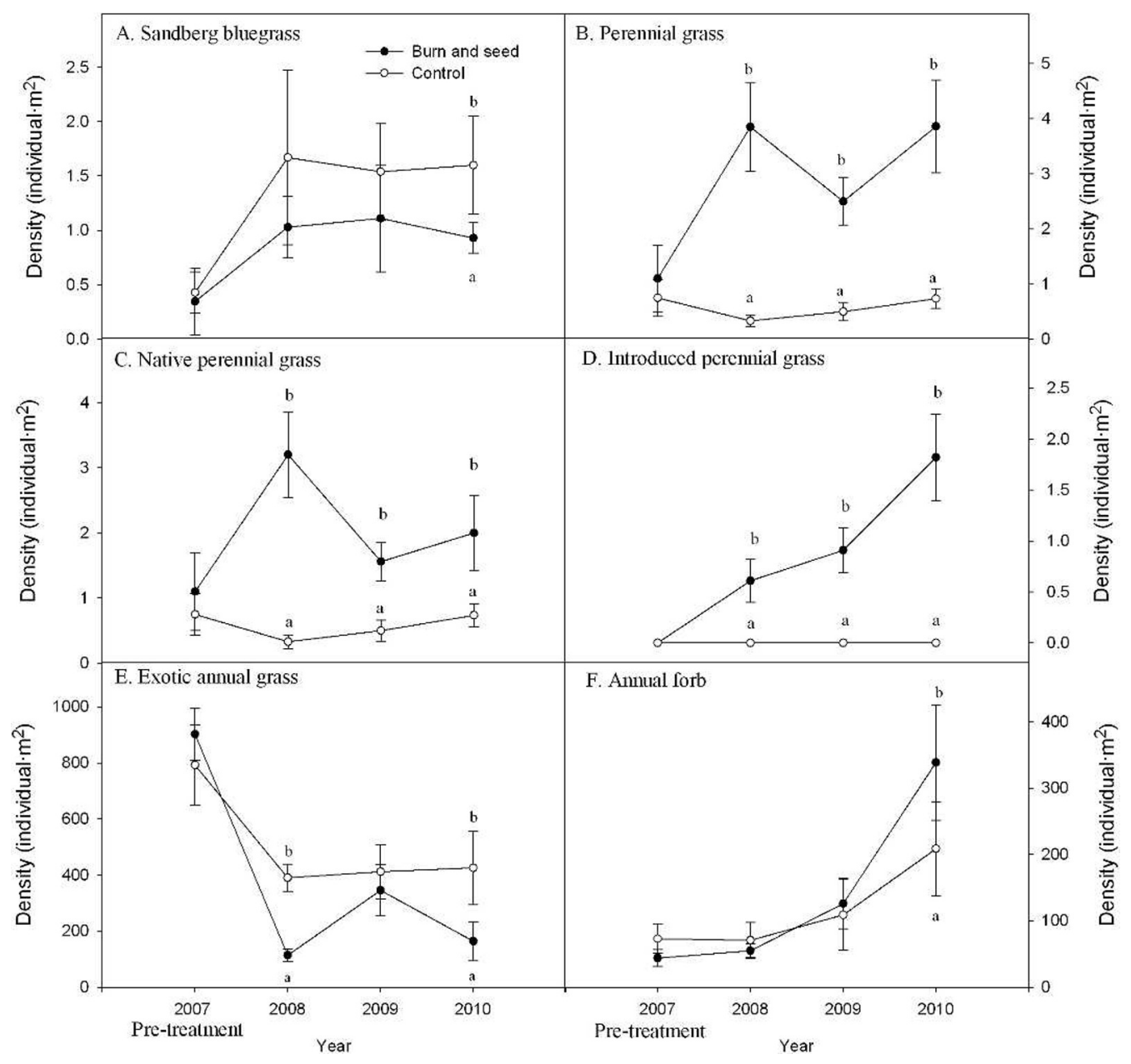

Figure 1. Mean \pm SE density of plant functional groups in medusahead-invaded plant communities that were drill-seeded after an early summer wildfires (burn and seed) or nontreated (control) in southeast Oregon. Control plots were not burned and not seeded. Perennial grass density was the sum of introduced and native perennial grass (excluding Sandberg bluegrass) densities. Different lowercase letters indicate differences between treatments in individual years $(P<0.05)$. Note that scale differs among figure panels.

treatments prior to treatment or in the first $2 \mathrm{yr}$ posttreatment (Fig. 3A; $P>0.05$ ). In the third year posttreatment, exotic annual grass cover was less in the burn-and-seed treatment compared to the control treatment $(P<0.01)$. Annual forb cover was greater in the control treatment than the burn-andseed treatment prior to treatment (Fig. 3B; $P<0.01$ ). After treatments were applied, annual forb cover was up to 6.2 -fold greater in the burn-and-seed treatment compared to the control treatment $(P<0.05)$. Total herbaceous vegetation (excluding exotic annual grasses) cover did not differ between treatments prior to treatment (Fig. 3C; $P=0.30$ ) or the first year posttreatment $(P=0.14)$. In the second and third years posttreatment, total herbaceous vegetation cover was 1.6- to 2.4-fold greater in the burn-and-seed treatment compared to the control $(P<0.05)$. Prior to treatment bare ground cover did not vary between treatments (Fig. 3D; $P=0.89$ ). Bare ground was between 1.4- and 7.2-fold greater in the burn-and-seed compared to the control treatment in the first $3 \mathrm{yr}$ posttreatment $(P<0.05)$. Perennial forb cover did not vary by treatment or the interaction between treatment and year (data not presented; $P>0.05$ ).

\section{DISCUSSION}

There appears to be some potential to capitalize on early summer wildfires in medusahead-invaded rangelands to achieve revegetation objectives. Fall seeding treatments applied after early summer wildfires generally led to a reduction in cover and density of exotic annual grass, an increase in several other plant functional groups, and an increase in bare ground as the medusahead thatch layer was reduced compared to the untreated control. These data support our hypotheses that annual grass cover and density would decrease and bare ground would increase with the burn-and-seed treatment. The increase observed in annual forbs and large bunchgrasses with the burnand-seed treatment suggests that there may be an opportunity to establish desirable vegetation in near-monocultures of medusahead following early summer wildfires. However, not all plant functional groups increased with the burn-and-seed treatment, thus our second hypothesis that all plant functional groups, excluding exotic annual grasses, would increase with treatment is only partially supported.

The causal effect of the increases in annual forbs and large bunchgrasses and decrease in medusahead cannot be attributed 


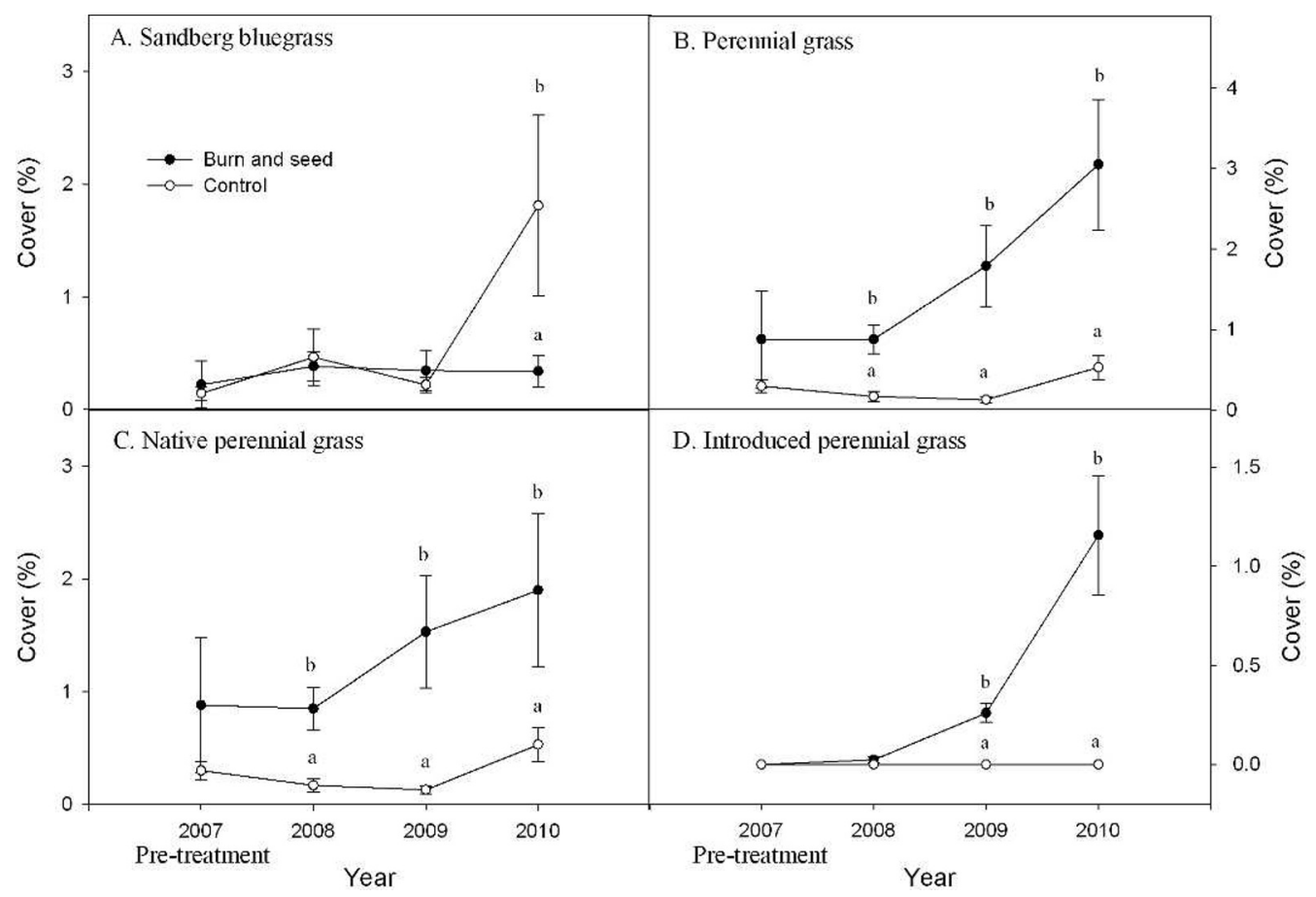

Figure 2. Mean \pm SE cover of plant functional groups in medusahead-invaded plant communities that were drill-seeded after an early summer wildfires (burn and seed) or nontreated (control) in southeast Oregon. Control plots were not burned and not seeded. Perennial grass cover was the sum of introduced and native perennial grass (excluding Sandberg bluegrass) cover values. Different lowercase letters indicate differences between treatments in individual years $(P<0.05)$. Note that scale differs among figure panels.

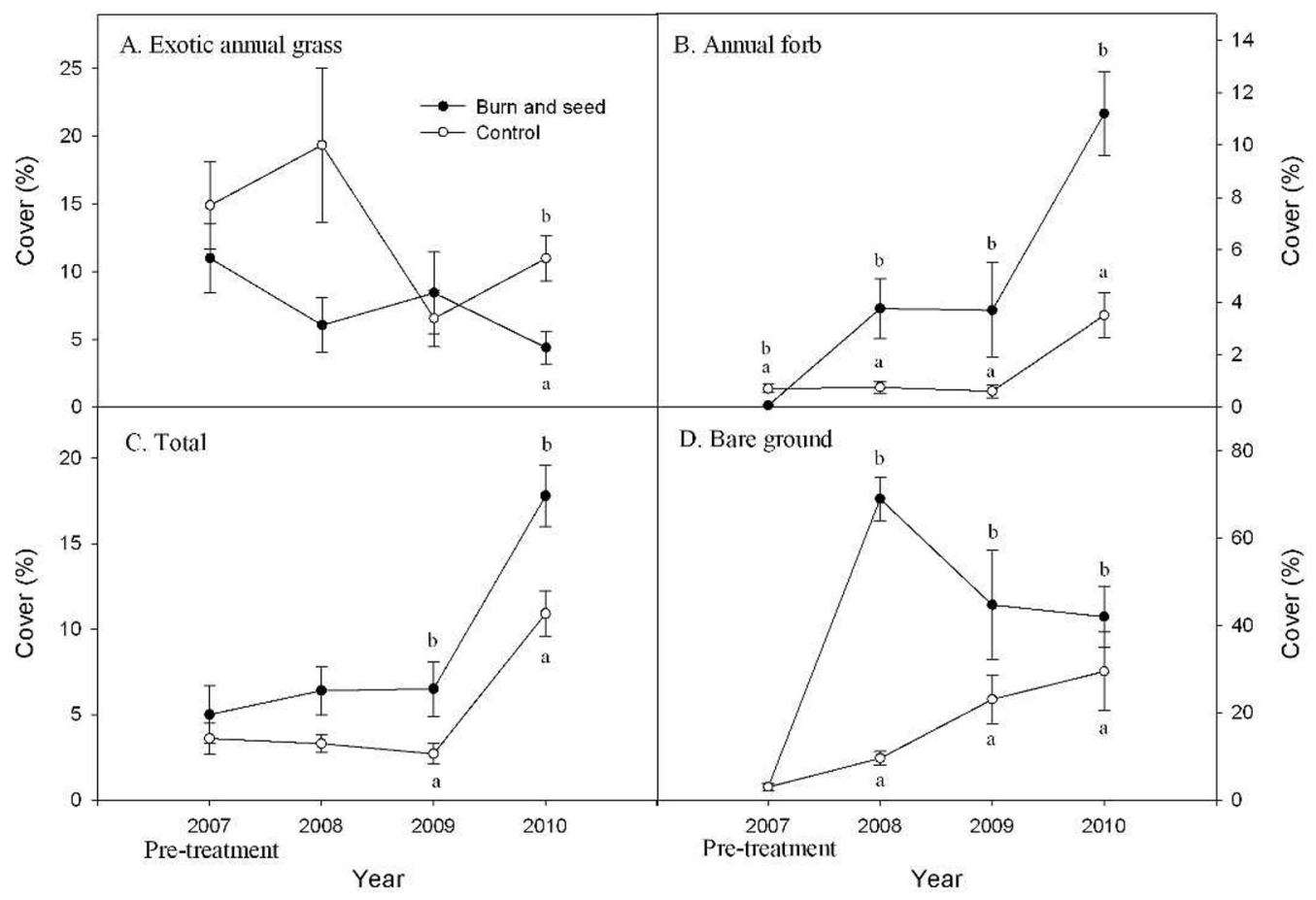

Figure 3. Mean \pm SE cover of plant functional groups and bare ground in medusahead-invaded plant communities that were drill-seeded after an early summer wildfires (burn and seed) or nontreated (control) in southeast Oregon. Control plots were not burned and not seeded. Total indicates total herbaceous vegetation excluding exotic annual grasses. Different lowercase letters indicate differences between treatments in individual years $(P<0.05)$. Note that scale differs among figure panels. 
solely to either the burning or seeding portion of the treatment, because they were not evaluated individually. Thus, we cannot definitely say that early summer wildfire controlled medusahead and increased annual forbs, that burning was needed to increase seeding success, or that seeding was beneficial. However, previous research found that burning without seeding did not increase perennial grasses (Young et al. 1972; Davies and Sheley 2011). In addition, seeding into untreated medusahead infestations was previously unsuccessful (Davies 2010). Considering that introduced perennial bunchgrasses were not present on our study sites before treatment (a treatment that included seeding them) and that they made up half of the total perennial bunchgrass density posttreatment (Fig. 1) supports our hypothesis that seeding was needed to increase perennial bunchgrasses. Though our results must be considered within the limitations imposed by not separating the effects of burning and seeding, there is some evidence to support the need for both treatments.

Though the increase in perennial grasses, excluding Sandberg bluegrass, with the burn-and-seed treatment is encouraging, the perennial grass density and especially the cover $(\sim 3 \%)$ were relatively low and may not be able to affect the long-term character of the site. Without adequate increases in perennial grasses, the sites will be susceptible to being converted back to a near-monoculture of medusahead. Increases in perennial grasses, excluding Sandberg bluegrass, are critical because they are the most important functional group for limiting medusahead in these plant communities (Davies 2008; James et al. 2008). The introduced perennial grasses showed some potential for continued increases as their cover and density were highest in the final sampling year and they can be competitive with medusahead (Davies et al. 2010). Therefore, introduced perennial grasses may continue to increase in the burn-andseed treatment, but longer-term evaluation will be needed to determine if this outcome is realized.

In contrast to the perennial grasses, perennial forbs did not appear to be influenced by treatment. This may be the result of only one perennial forb being included in the seed mix and the general lack of perennial forb response to treatments in these ecosystems. Perennial forbs have been reported to not respond to prescribed burning (Nelle et al. 2000; Davies et al. 2007; Beck et al. 2009; Rhodes et al. 2010), mechanical brush control (Davies et al. 2011), or preemergent herbicide control of exotic annual grasses (Davies 2010) in sagebrush plant communities. However, Wirth and Pyke (2003) reported that survival of seeded perennial forbs was greater in burned compared to unburned sagebrush communities. Increases in perennial forbs without seeding appear unlikely in these plant communities. Our study did not adequately test the potential for increasing perennial forbs with seeding, because only one perennial forb was seeded postfire.

We observed a large response among annual forbs, predominately natives, in areas burned by early summer wildfires. Similar to our results, Davies (2010) reported that spring and fall prescribed burning increased annual forbs in medusaheadinvaded plant communities. Annual forbs have also been reported to increase after prescribed burning sagebrush communities not invaded by exotic annual grasses (Rhodes et al. 2010; Bates et al. 2011). Annual forb responses are generally considered ephemeral in this ecosystem (Bates 2004), but the increase in annual forbs in our study had not diminished by the third year posttreatment. Longer-term evaluation will be needed to determine if the annual forb response is ephemeral. The increase in total herbaceous vegetation was largely the response of perennial grasses and annual forbs, thus their responses over time will probably determine the long-term response of total herbaceous vegetation.

Exotic annual grass cover and density were less in the burnand-seed treatment compared to the control at the end of the study. Medusahead was probably reduced because the wildfire occurred prior to seed maturity. Burning at this time has been demonstrated to control medusahead by reducing viable seeds (Murphy and Lusk 1961; McKell et al. 1962). The establishment of perennial grasses may also have limited medusahead. Perennial grasses overlap in resource use with medusahead (James et al. 2008) and they are the most important functional group for limiting medusahead establishment (Davies 2008). However, exotic annual grass density was still over 130 individuals $\cdot \mathrm{m}^{-2}$ in the third year posttreatment, which may pose a significant threat to the long-term success of this revegetation effort. Because medusahead is competitive with native vegetation (Hironaka and Sindelar 1975; Young and Mangold 2008), it may, over time, displace native vegetation that increased with the burn-and-seed treatment. The medusahead remaining in the community may also increase fine fuel loads and increase wildfire frequency, which would probably cause declines in native perennial vegetation (Torell et al. 1961; D'Antonio and Vitousek 1992; Brooks et al. 2004).

\section{MANAGEMENT IMPLICATIONS}

Seeding after early summer wildfires appears to have potential to increase perennial grasses and annual forbs and reduce exotic annual grass dominance; however, we cannot definitely say that the combined treatment was needed because we did not individually apply early summer wildfires or seeding treatments. Though the initial response to the burn-and-seed treatment appears promising, perennial grass density and cover were lower than desired and exotic annual grasses were still a prominent component of the plant community. This poses a significant risk of converting back to a near-monoculture of medusahead. Based on the success of using preemergent herbicides to revegetate medusahead-invaded rangelands ( $\mathrm{Da}-$ vies 2010), treating the plant community with a preemergent herbicide after the wildfire would probably have increased the establishment of perennial grasses and yielded better control of medusahead. The seeding of perennial grasses would probably have to be postponed $1 \mathrm{yr}$ to decrease the risk of their mortality from the preemergent herbicide. The plant community may also have responded favorably to a preemergent herbicide application after perennial grasses had established to reduce competition from medusahead. Capitalizing on early summer wildfires may represents an opportunity to reduce treatment costs associated with revegetating medusahead-invaded plant communities; however, additional research is needed to determine causal mechanisms and to evaluate the need for additional control treatments to reduce competition from medusahead and increase the success of the seeded species and subsequent seedling establishment. 


\section{ACKNOWLEDGMENTS}

The authors thank Julie Garner, Carrie Cimo, Ryan Morgan, Jen Trenary, Patrick Haley, Savannah Duff, Brandi Carlon, and Sarah Fitzpatrick for data collection. The authors also thank the Burns and Vale Bureau of Land Management districts for allowing this research project to occur on lands they administer and applying the drill-seeding treatment. Thoughtful reviews of this manuscript by Matt Madsen, Dave Ganskopp, and anonymous reviewers were greatly appreciated.

\section{LITERATURE CITED}

BAteS, J. 2004. Interannual productivity in burned and unburned Wyoming big sagebrush-grassland. In: Range field day report: current forage and livestock production research. Corvallis, OR, USA: Oregon State University. Special Report 1052. p. 17-23.

Bates, J. D., K. W. Davies, and R. N. Sharp. 2011. Shrub-steppe early succession following juniper cutting and prescribed fire. Environmental Management 47:468-481.

Beck, J. L., J. W. Connelly, and K. P. Reese. 2009. Recovery of greater sage-grouse habitat features in Wyoming big sagebrush following prescribed fire. Restoration Ecology 17:393-403.

Boyd, C. S., And K. W. Davies. 2010. Shrub microsite influences post-fire perennial grass establishment. Rangeland Ecology \& Management 63:248-252.

Brooks, M. L., C. M. D’Antonio, D. M. Richardson, J. B. Grace, J. E. Keeley, J. M. Ditomaso, R. J. Hobbs, M. Pellant, and D. Pyke. 2004. Effect of invasive alien plants on fire regimes. BioScience 54:677-688.

D'Antonio, C. M., And P. M. Vitousek. 1992. Biological invasions by exotic grasses, the grass/fire cycle, and global change. Annual Reviews in Ecology and Systematics 23:63-87.

DAVIES, K. W. 2008. Medusahead dispersal and establishment in sagebrush steppe plant communities. Rangeland Ecology \& Management 61:110-115.

DaviEs, K. W. 2010. Revegetation of medusahead-invaded sagebrush steppe. Rangeland Ecology \& Management 63:564-571.

Davies, K. W. 2011. Plant community diversity and native plant abundance decline with increasing abundance of an exotic annual grass. Oecologia 167:481-491.

Davies, K. W., J. D. Bates, and R. F. Miller. 2007. Short-term effects of burning Wyoming big sagebrush steppe in southeast Oregon. Rangeland Ecology \& Management 60:515-522.

Davies, K. W., J. D. Bates, and A. M. Nafus. 2011. Are there benefits to mowing intact Wyoming big sagebrush communities? An evaluation from southeastern Oregon. Environmental Management 48:539-546.

Davies, K. W., A. M. Nafus, and R. L. Sheley. 2010. Non-native competitive perennial grass impedes the spread of an invasive annual grass. Biological Invasions 12:3187-3194.

Davies, K. W., and R. L. Sheley. 2011. Promoting native vegetation and diversity in exotic annual grass infestations. Restoration Ecology 19:159-165.

Davies, K. W., AND T. J. SveJcaR. 2008. Comparison of medusahead-invaded and noninvaded Wyoming big sagebrush steppe in southeastern Oregon. Rangeland Ecology \& Management 61:623-629.

Ditomaso, J. M., M. L. Brooks, E. B. Allen, R. Minnich, P. M. Rice, and G. B. Kyser. 2006. Control of invasive weeds with prescribed burning. Weed Technology 20:535-548.

Duncan, C. E., J. J. Jachetta, M. L. Brown, V. F. Carrithers, J. K. Clark, J. M. DiTomaso, R. G. Lym, K. C. McDaniel, M. J. Renz, and P. M. Rice. 2004. Assessing the economic, environmental, and societal losses from invasive plants on rangelands and wildlands. Weed Technology 18:1411-1416.
Hironaka, M. 1961. The relative rate of root development of cheatgrass and medusahead. Journal of Range Management 14:263-267.

HironaKa, M., AND B. W. SindeLAR. 1975. Growth characteristics of squirreltail seedlings in competition with medusahead. Journal of Range Management 28:283-285.

HuLL, A. C., JR. 1974. Species for seeding arid rangeland in southern Idaho. Journal of Range Management 27:216-218.

James, J. J., K. W. Davies, R. L. Sheley, and Z. T. Aanderud. 2008. Linking nitrogen partitioning and species abundance to invasion resistance in the Great Basin. Oecologia 156:637-648.

Kyser, G. B., M. P. Doran, N. K. McDougald, S. B. Orloff, R. N. Vargas, R. G. Wilson, AND J. M. DITomaso. 2008. Site characteristics determine the success of prescribed burning for medusahead (Taeniatherum caput-medusae) control. Invasive Plant Science and Management 1:376-384.

Littell, R. C., G. A. Mllliken, W. W. Stroup, and R. D. Wolfinger. 1996. SAS System for Mixed Models. Cary, NC, USA: SAS Institute Inc. 633 p.

Liu, J., M. Dong, S. L. Miao, Z. Y. LI, M. H. Song, and R. Q. Wang. 2006. Invasive alien plants in China: role of clonality and geographical origin. Biological Invasions 8:1461-1470.

Mack, R. N. 1981. Invasion of Bromus tectorum L. into western North America: an ecological chronicle. Agro-Ecosystems 7:145-165.

McKell, C. M., A. M. WILSON, AND B. L. Kay. 1962. Effective burning of rangelands infested with medusahead. Weeds 10:125-131.

McLean, A., and E. W. Tisdale. 1972. Recovery rate of depleted range sites under protection from grazing. Journal of Range Management 25:178-184.

Monaco, T. A., T. M. Osmond, And S. A. Dewey. 2005. Medusahead control with falland spring-applied herbicides in northern Utah foothills. Weed Technology 19:653-658.

Murphy, A. H., and W. C. Lusk. 1961. Timing of medusahead burns. California Agriculture 15:6-7.

Nelle, P. J., K. P. Reese, and J. W. Connelly. 2000. Long-term effects of fire on sage grouse habitat. Journal of Range Management 53:586-591.

Oregon Climate Service. 2009. Oregon Climate Data. Available at: http://www.ocs.orst. edu/oregon-climate-data. Accessed 1 September 2009.

PuRdie, R. W., AND R. O. Slatyer. 1976. Vegetation succession after fire in sclerophyll woodland communities in south-eastern Australia. Australian Journal of Ecology 1:223-236.

Rhodes, E. C., J. D. Bates, R. N. Sharp, and K. W. Davies. 2010. Fire effects on cover and dietary resources of sage-grouse habitat. Journal of Wildlife Management $74: 755-764$

Robertson, J. H., R. E. ECkert, and A. T. Bleak. 1966. Response of grasses seeded in an Artemisia tridentata habitat in Nevada. Ecology 47:187-194.

Torell, P. J., L. C. ERickson, and R. H. HaAs. 1961. The medusahead problem in Idaho. Weeds 9:124-131.

usda-Natural Resource Conservation Service. 2008. Soil Survey. Available at: http:// websoilsurvey.nrcs.usda.gov. Accessed 19 December 2008.

Winward, A. H. 1980. Taxonomy and ecology of sagebrush in Oregon. Corvallis, OR, USA: Oregon State University. Agricultural Experiment Station Bulletin 642. $15 \mathrm{p}$.

WiRTh, T. A., AND D. A. PykE. 2003. Restoring forbs for sage grouse habitat: fire, microsites, and establishment methods. Restoration Ecology 11:370-377.

Yensen, E., D. L. Quinney, K. Johnson, K. Timmerman, and K. Steenhof. 1992. Fire, vegetation changes, and population fluctuations of Townsend's ground squirrels. American Midland Naturalist 128:299-312.

Young, J. A. 1992. Ecology and management of medusahead (Taeniatherum caputmedusae ssp. asperum [SIMK.] Melderis). Great Basin Naturalist 52:245-252.

Young, J. A., R. A. Evans, AND J. RoBinson. 1972. Influence of repeated annual burning on a medusahead community. Journal of Range Management 25:372-375.

Young, K., AND J. MangoLd. 2008. Medusahead outperforms squirreltail through interference and growth rate. Invasive Plant Science and Management 1:73-81. 